\title{
Unreported Aflatoxins and Hydroxylate Metabolites in Artisanal Oaxaca Cheese from Veracruz, Mexico
}

\section{Vargas-Ortiz $\mathbf{M}^{1,2}$, Carvajal-Moreno $\mathbf{M}^{1 *}$, Hernández-Camarillo $\mathrm{E}^{1,3}$, Ruiz-Velasco $\mathrm{S}^{4}$ and Rojo-Callejas $\mathrm{F}^{5}$}

${ }^{1}$ Laboratorio C-119 De Micotoxinas, Departamento de Botánica, Instituto de Biología, Ciudad Universitaria, Universidad Nacional Autónoma de México (UNAM), CP 04510 CdMx, México.

${ }^{2}$ CONACYT-CIAD (Centro de Investigación en Alimentación y Desarrollo), Coordinación Culiacán. Carretera El Dorado Km 5.5, Col. Campo El Diez, Culiacán Sinaloa 80110, México.

3Instituto Tecnológico de Veracruz, Tecnológico Nacional de México, SEP, Calzada Miguel Angel de Quevedo 2779, Col. Formando Hogar, CP 91897 H. Veracruz, Ver., México. ${ }^{4}$ Departamento de Probabilidad y Estadística, Instituto de Investigaciones en Investigaciones y en Sistemas, Ciudad Universitaria, UNAM, CP 04510 CdMx, México. ${ }^{5}$ Departamento de Química Analítica, Facultad de Química, Ciudad Universitaria, Universidad Nacional Autónoma de México (UNAM), CP 04510 CdMx, México.

\begin{abstract}
Aflatoxins (AFs) are toxic secondary metabolites of the fungi Aspergillus flavus, $A$. parasiticus and $A$. nomius. The fungi produce these AFs in cereals, oilseeds and spices. AFs have damaging effects on all organisms, including humans, and their symptoms can be classified as acute (vomiting, hemorrhage and death) or chronic (immunodepression, Reye syndrome, Kwashiorkor, teratogenesis, hepatitis, cirrhosis, and various cancers). The common $A_{F s}\left(A_{F}, A_{1} B_{2}, A_{1}\right.$, $\left.A F G_{2}\right)$ are metabolized in the liver or by microbes that produce hydroxylates (AFM $\left., A F M_{2}, A F P_{1}\right)$ and aflatoxicol $(A F L)$, which makes them soluble in water. This means that AFs can be excreted in fluids such as milk or urine, and AFs are not destroyed in the process of making cheese.

Other AFs can also be excreted in milk, but they have not been reported until now. The purpose of this study was to identify and quantify the AFs present in 30 samples of artisanal Oaxaca-type cheese sold in the City of Veracruz. The average concentrations of AFs detected in the 30 samples of artisanal cheese were AFB $\left(11.2 \mathrm{ng} \mathrm{g}^{-1}\right)$ in $77 \%(23 / 30)$; AFL (19.1 $\left.\mathrm{ng} \mathrm{g}^{-1}\right)$ in 70\% (21/30); $\mathrm{AFG}_{2}\left(0.2 \mathrm{ng} \mathrm{g}^{-1}\right)$ in 63\% (19/30); $\mathrm{AFM}_{1}\left(3.0 \mathrm{ng} \mathrm{g}^{-1}\right)$ in 53\% (16/30); $\mathrm{AFP}_{1}\left(0.1 \mathrm{ng} \mathrm{g}^{-1}\right)$ in 50\% (15/30); AFM $_{2}\left(0.2 \mathrm{ng} \mathrm{g}^{-1}\right)$ in $20 \%(6 / 30) ; \mathrm{AFG}_{1}\left(0.03 \mathrm{ng} \mathrm{g}^{-1}\right)$ in $13 \%(4 / 30)$; and a trace amount of AFB $(<\mathrm{LOD})$ in only $3 \%(1 / 30)$. AFB 1 and AFL are the most abundant AFs in Oaxaca-type cheese, although eight $A F s$ were present, contributing to an average of 33.9 AFs distributed among the 30 samples. Cheese can therefore be associated with a certain degree of risk for cancer development.
\end{abstract}

Keywords: Aflatoxins; Fresh cheese; Carcinogens; Food contamination

\section{Introduction}

Cheese is an economically important commodity worldwide. In Mexico, 76,696 tons of Oaxaca-type cheese were produced in 2005, with a value of 2,700 million Mexican pesos [1,2]. Most of the information about aflatoxins (AFs) in cheese is related to industrial production and sale through formal commercialized channels. However, most of the Oaxaca-type cheese consumed in Mexico is handmade artisanally, and there have been no reports about AFs in cheese and the quantities sold in Mexico.

The State of Veracruz is the sixth largest producer of milk in Mexico [3], and $53 \%$ of the total milk produced in the state is used without pasteurization to produce artisanal cheeses [4], which are sold in large cities such as the Port of Veracruz. One of the main artisanal cheeses produced in this region is Oaxaca-type cheese, which is made in the same way throughout the country. The process begins with warming milk to temperatures between $18^{\circ} \mathrm{C}$ and $25^{\circ} \mathrm{C}$; the milk is then heated to $38^{\circ} \mathrm{C}$, and rennet is added $(9-12 \mathrm{~mL}$ for $100 \mathrm{~L}$ of milk). The milk is then acidified with acetic acid at $\mathrm{pH} 5.5$, and upon curdling the curds are cut into $2-\mathrm{cm}$ squares. The curds are left to rest for $25 \mathrm{~min}$ and are later shredded by hand and left to acidify for $20 \mathrm{~min}$. The whey is drained, and the curds without whey are melted when mixed with hot water $\left(60^{\circ} \mathrm{C}\right)$. The product is stretched by hand to form threads of $3 \mathrm{~cm}$ to 6 $\mathrm{cm}$ wide and then cooled with water $\left(18^{\circ} \mathrm{C}\right)$. The cheese is left to drain, and salt is added ( $11 \mathrm{~g}$ to $50 \mathrm{~g}$ salt per $1 \mathrm{~kg}$ of threads). Finally, ball hanks are formed with the cheese threads [5].

Aflatoxins (AFs) are toxic secondary metabolites that chemically correspond to bis-dihydro-furanecoumarins and have well-known physicochemical properties [6]. AFs are mainly produced by the fungi Aspergillus flavus, A. parasiticus and A. nomius [7]. The common AFs found in cereals, which are present in balanced cow feed, are aflatoxin $\mathrm{B}_{1}\left(\mathrm{AFB}_{1}\right)$ and aflatoxin $\mathrm{B}_{2}\left(\mathrm{AFB}_{2}\right)$, which have blue fluorescence, and aflatoxin $G_{1}\left(A F G_{1}\right)$ and aflatoxin $G_{2}\left(A F G_{2}\right)$, which have green fluorescence [8].

The acute symptoms of AFs include vomiting, miscarriage, hemorrhage, diarrhea and death, and chronic symptoms include immunosuppression, fetal malformation, hepatitis B and C, cirrhosis, and carcinoma of the liver $[9,10]$, cervix [11], colorectal system [12], breast [12] and pancreas [12]. AFs are considered potent carcinogens, and the International Organization for the Research on Cancer (IARC) classified them as Grade I in humans [13].

AFs can be present in balanced cattle feed [14] in countries with tropical weather, where high humidity and warm temperatures in storage warehouses facilitate fungal growth, as well as in agricultural

*Corresponding author: Magda Carvajal-Moreno, Laboratorio C-119 de Micotoxinas, Departamento de Botánica, Instituto de Biología, Ciudad Universitaria, Universidad Nacional Autónoma de México (UNAM), Coyoacán CP 04510 CdMx, México, Tel: +(5255) 56229138 Fax: +(5255) 55501760 E-mail:magdac@ib.unam.mx

Received: March 09, 2017; Accepted: June 12, 2017; Published June 15, 2017

Citation: Vargas-Ortiz M, Carvajal-Moreno M, Hernández-Camarillo E, RuizVelasco S, Rojo-Callejas F (2017) Unreported Aflatoxins and Hydroxylate Metabolites in Artisanal Oaxaca Cheese from Veracruz, Mexico. Biochem Anal Biochem 6: 322. doi: 10.4172/2161-1009.1000322

Copyright: ( 2017 Vargas-Ortiz M, et al. This is an open-access article distributed under the terms of the Creative Commons Attribution License, which permits unrestricted use, distribution, and reproduction in any medium, provided the original author and source are credited. 
and unregulated local markets [15]. Cheese is an important source of nutrients for humans, and it is frequently contaminated with AFs [16]. AFs are present in the cereals and oilseeds that are used as ingredients in feed and silage for cattle [17]. They are common in countries where storage, harvest and climate conditions are suitable for fungal growth and in countries without food regulation legislation $[17,18]$.

When dairy cattle consume fodder contaminated with $\mathrm{AFB}_{1}$ or $\mathrm{AFB}_{2}$, these toxins are rapidly absorbed. The animal's liver and the microbial metabolism mitigates the damaging effects of the toxins by introducing a hydroxyl $\left(\mathrm{OH}^{-}\right)$into the AF molecule, forming hydroxylate metabolites that allow the toxins to be dissolved in water and expelled from the body via urine or milk. In this way, $\mathrm{AFB}_{1}, \mathrm{AFB}_{2}$, $\mathrm{AFG}_{1}$ and $\mathrm{AFG}_{2}$ from balanced feed of ruminants or from fodder are biotransformed into $\mathrm{AFM}_{1}, \mathrm{AFM}_{2}, \mathrm{AFP}_{1}$ and aflatoxicol (AFL) [19], and these less toxic but still carcinogenic hydroxylate metabolites are secreted in cow's milk (Figure 1).

\section{Aflatoxins in cheese}

AFs bind to proteins such as milkcasein via a hydrophobicinteraction [20]. Therefore, $\mathrm{AFM}_{1}$ is present in cheese when contaminated milk is used. $\mathrm{AFM}_{1}$ distributes in a $40 \%$ to $60 \%$ ratio between curd and whey, depending on the cheese-making method [21]. AFM can withstand temperatures up to $320^{\circ} \mathrm{C}$ before decomposing and is resistant to thermal treatments, such as pasteurization, ultrapasteurization and acidification, that are used during the processing of cheeses [22,23]. Although $\mathrm{AFM}_{1}$ is less toxic than $\mathrm{AFB}_{1}$, it is still carcinogenic, and it is frequently reported in dairy products. Nonetheless, other AFs certainly contribute to the risk associated with AFs due to the high

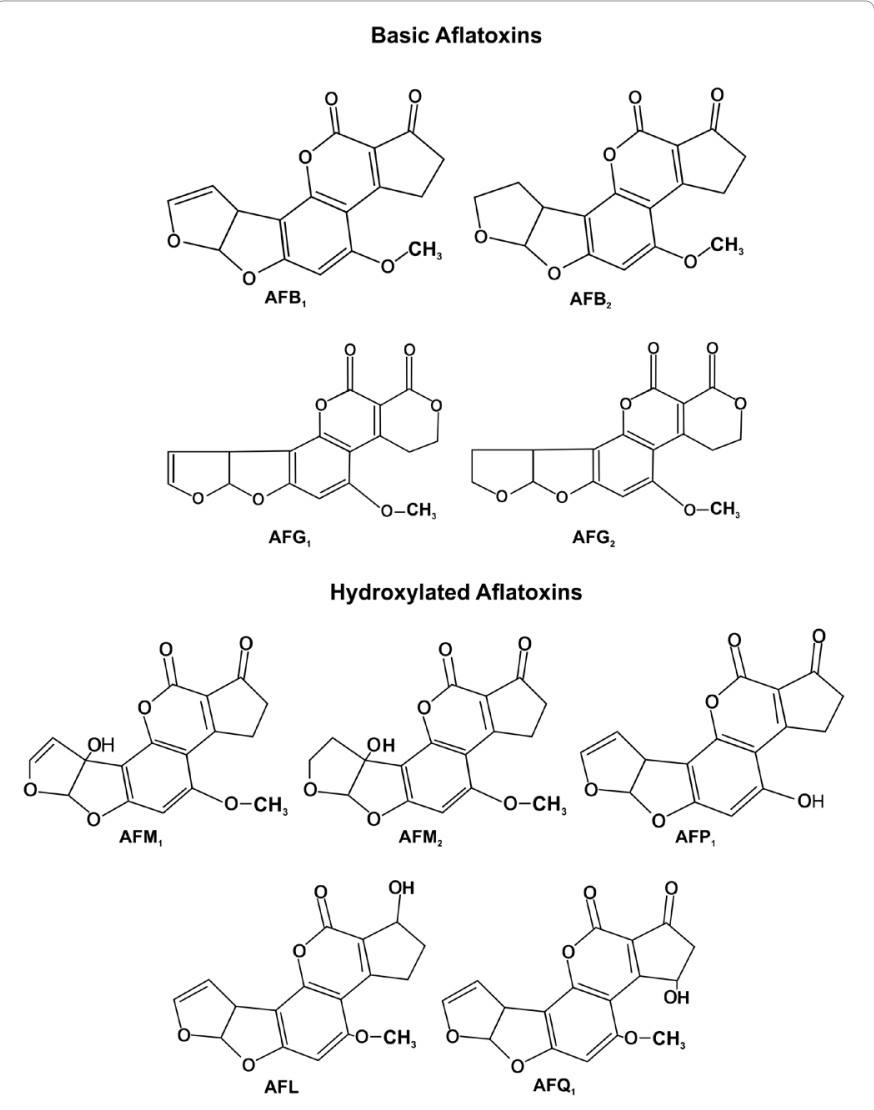

Figure 1: Chemical structure of aflatoxins.

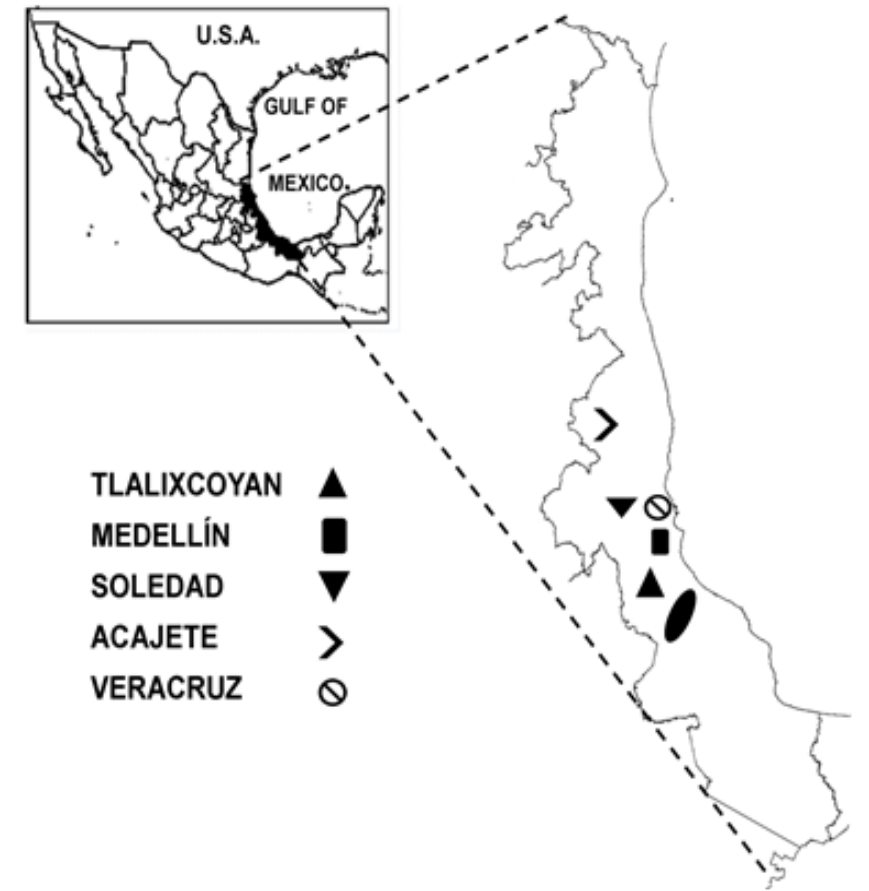

Figure 2: Origin of samples from the State of Veracruz, bought in the City of Veracruz.

consumption of dairy products. Therefore, many countries have established regulations for the maximum tolerable levels of AFs in milk and dairy products [24]. $\mathrm{AFM}_{1}, \mathrm{AFM}_{2}, \mathrm{AFB}_{1}$ and AFL have been reported in Mexican milk [25,26]. Oaxaca-type cheese has economic, cultural and alimentary importance; therefore, the detection of AFs in artisanal cheeses commercialized in Veracruz is necessary. The purpose of this research was to find other $\mathrm{AFs}\left(\mathrm{AFB}, \mathrm{AFB}, \mathrm{AFG}, \mathrm{AFG}_{2}\right)$ and the hydroxylate metabolites $\mathrm{AFM}_{1}$ and $\mathrm{AFM}_{2}$ for comparison as well as $\mathrm{AFP}_{1}$ and $\mathrm{AFL}$, which have not been reported, and to discuss their importance as carcinogens.

\section{Materials and Methods}

\section{Sampling}

The study consisted of 30 samples of $750 \mathrm{~g}$ of Oaxaca-type artisanal handmade cheese purchased in groceries and markets in the City of Veracruz. The cheese samples originated from 5 townships (Acajete, Medellin, Tlalixcoyan, Soledad and Veracruz) of the State of Veracruz, Mexico (Figure 2). These townships practice dual-purpose cattle raising for both meat production and small artisanal cheese making with no sanitary legislation. A Matlab algorithm was used to randomly select the places from which the samples were purchased in the City of Veracruz. The cheeses were refrigerated immediately after sampling and were subjected to a drying process for a period of less than 12 hours. Samples of Oaxaca-type cheeses were purchased in March 2016, which is in the dry season when the cows are fed nutritionally balanced feed; during the rest of the year, cows typically eat grass.

Each cheese sample was manually unthreaded, the cheese samples were placed in a tray drier, and the dry samples were stored frozen until $\mathrm{AF}$ extraction and chemical analysis were performed.

\section{Chemical extraction method for Aflatoxins}

The R-Biopharm [27] method has been recommended for use 
with Total aflatoxin Easi-Extract Immunoaffinity Columns (IAC) (R-Biopharm Rhône Ltd., Glasgow, Scotland, UK). This method was performed according to the following protocol.

First, 15 g samples of dry, ground Oaxaca-type cheese were blended (Waring ETL laboratory blender 7010S model WF 2211214, Torrington, CT, USA) for 2 minutes at high speed with a mixture of $100 \mathrm{~mL}$ of $\mathrm{MeOH} /$ water $(80: 20 \mathrm{v} / \mathrm{v})$ and $2 \mathrm{~g} \mathrm{NaCl}$ to clarify the extract. The mixture was centrifuged at $4500 \mathrm{rpm}$ for $15 \mathrm{~min}$, and an amount of supernatant equivalent to $1 \mathrm{~g}$ of sample was dissolved in phosphatebuffered saline (PBS) at $\mathrm{pH} 7.4$ at a proportion of $1: 4(\mathrm{v} / \mathrm{v})$ and homogenized for 1 minute in a vortex. Before adding the samples, each IAC was equilibrated with $20 \mathrm{~mL}$ of PBS at $\mathrm{pH} 7.4$ applied at a flux of $5 \mathrm{~mL} / \mathrm{min}$. The buffered sample was passed through the IAC, and AFs were eluted using $1.5 \mathrm{~mL}$ of HPLC-grade $\mathrm{MeOH}$ followed by $1.5 \mathrm{~mL}$ of distilled water with reflux. The eluate was dried at $40^{\circ} \mathrm{C}$ in an oven (F135A Novatech Model, México City, Mexico) and then derivatized.

\section{Derivatization}

Derivatization is a process to increase the AF fluorescence [28,29] of AF standards to make calibration curves and to quantify the AFs in cheese samples Figure 3. The derivatization reaction with trifluoroacetic acid is the transformation of $\mathrm{AFB}_{1}$ and $\mathrm{AFG}_{1}$ that are less fluorescents, in their hemiacetals $\mathrm{B}_{2 \mathrm{a}}$ abd $\mathrm{AFG}_{2 \mathrm{a}}$ that are highly fluorescent. $\mathrm{AFB}_{2}$ and $\mathrm{AFG}_{2}$ are not affected by this reaction due to their saturated structure [28].

Eight dry AF standards $\left(\mathrm{AFB}_{1}, \mathrm{AFB}_{2}, \mathrm{AFG}_{1}, \mathrm{AFG}_{2}, \mathrm{AFM}_{1}, \mathrm{AFM}_{2}\right.$, $\mathrm{AFP}_{1}$ and AFL from Sigma-Aldrich; St. Louis, MO, USA) that were used to determine the AFs' linearity and percentage of recovery validation were dissolved in $200 \mu \mathrm{L}$ of HPLC-grade acetonitrile (ACN), and $800 \mu \mathrm{L}$ of derivatization solution was added. The derivation solution was prepared with $5 \mathrm{~mL}$ of trifluoroacetic acid (Sigma-Aldrich, St. Louis, MO, USA), $2.5 \mathrm{~mL}$ glacial acetic acid (Merck, Naucalpan, Estado de Mexico, Mexico) and $17.5 \mathrm{~mL}$ deionized distilled water and then vortexed (Vortex G-560, Bohemia, NY, USA) for 30 seconds. The vials containing the dry eluates were heated in a vapor bath at $65^{\circ} \mathrm{C}$ for $10 \mathrm{~min}$. The derivatized samples were cooled to room temperature, and triplicate $60-\mu \mathrm{L}$ samples were analyzed by HPLC with fluorescence (HPLC-FL).

\section{Validation of the extraction method}

The validation of the analytical method and the analysis of the 30 Oaxacatype cheese samples were performed using known parameters [30].
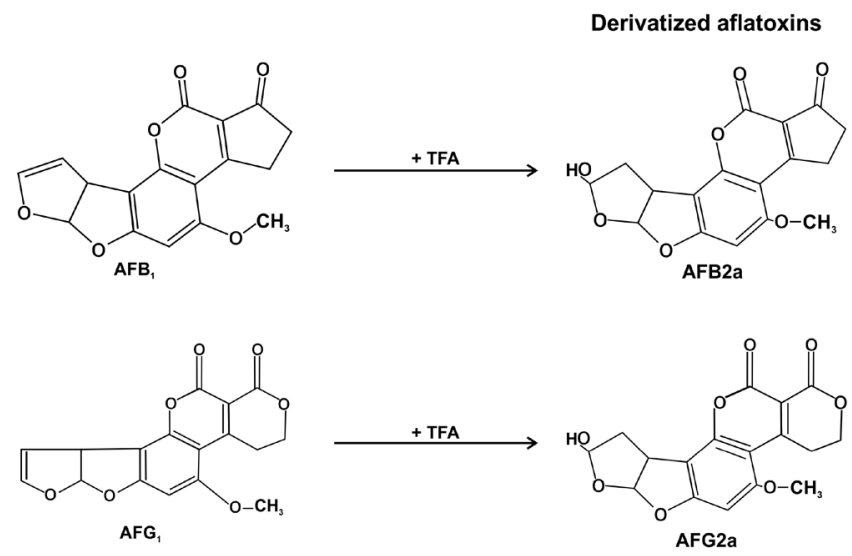

Figure 3: The derivatization reaction with trifluoroacetic acid that transforms $A F B_{1}$ and $A F G_{1}$, lessfluorescent, in their hemiacetals $B_{2 a}$ and $A F G_{2 a}$ that are highly fluorescent. $A F B_{2}$ and $A F G_{2}$ are not affected due to their saturated structure.

\section{Linearity of the system (Calibration curves)}

Solutions with different concentrations of AFs were prepared from a stock concentration of $1000 \mathrm{ng}$ AFM. The $0.25 \mathrm{mg}$ AFM standards were diluted with benzene:acetonitrile $(98: 2 \mathrm{v} / \mathrm{v})$, following a previously reported methodology [31], so that the pure AFs did not decompose.

a. The spectrophotometer (Genesys 10 UV Thermo Electron Corporation. Madison, WI, USA) was calibrated before the experiments to measure the absorbance of the AFM standard solutions at $357 \mathrm{~nm}$.

b. Different formulas [31] were applied to calculate $1000 \mathrm{ng}$ stock solutions of each AF concentration:

c. Twelve concentrations $(0.01,0.05,0.1,0.5,1,2,4,8,16,32,64$ and $128 \mathrm{ng}$ ) of the 8 different AFs were independently created from the $1000 \mathrm{ng}$ stock solution. These standard dilutions were then used to plot the analytic signal (area below the curve of each chromatographic peak) against the AF concentrations. The curve equation and statistical parameters were obtained. The slope value $\left(b_{1}\right)$, ordinate to origin $\left(b_{0}\right)$, determination coefficient $\left(\mathrm{R}^{2}\right)$, confidence interval for the slope to origin $(\operatorname{IC}(\beta))$, variation coefficient percentage $(\% \mathrm{CV})$, standard deviation (SD), and the LOD and LOQ were calculated using Excel 2003.

\section{LOD and LOQ}

The LOD of the equipment was established in relation to the noise in the chromatogram. The LOD is equal to the AF concentration that gives a signal three times greater than the noise. The LOQ equals the AF concentration that is 10 times greater than the noise [32].

\section{Recovery percentages}

The recovery percentage is a measure of the accuracy of the method and expresses the proximity between the theoretical and experimental values. The arithmetic average, standard deviation, percentage of variation coefficient and confidence interval were calculated. To obtain accurate measurements, the AFs of the samples of dried, ground Oaxaca-type cheese, in $1 \mathrm{~g}$ aliquots, diluted in PBS $(1: 4 \mathrm{v} / \mathrm{v})$, were individually spiked with three different concentrations $(5,20$ and 40 $\left.\mu \mathrm{g} \mathrm{kg}^{-1}\right)$ of the eight individual AF standards $\left(\mathrm{AFB}_{1}, \mathrm{AFB}_{2}, \mathrm{AFG}_{1}, \mathrm{AFG}_{2}\right.$ $\mathrm{AFM}_{1}, \mathrm{AFM}_{2}, \mathrm{AFP}_{1}$ ) and $\mathrm{AFL}$; one aliquot without spiked $\mathrm{AF}$ was used as the control, which gave the basal contamination level. The samples were individually processed using the R-Biopharm extraction method [27]. AFs were purified and concentrated using an IAC, derivatized, and quantified by HPLC-FL, and the percentage of recovery for each $\mathrm{AF}$ was obtained. After the derivatization mixture was cooled to room temperature, triplicates of $60 \mu \mathrm{L}$ of each sample were injected into the HPLC-FL method.

\section{HPLC-FL quantitation}

The HPLC-FL chromatographic system was an Agilent Series 1200 HPLC (Agilent Technologies, Inc., Santa Clara CA, USA) and consisted of an isocratic pump (Model G1310A); a fluorescence detector (Model G1310A Series DE62957044, Agilent Technologies, Inc., USA), which was set to an excitation wavelength of $360 \mathrm{~nm}$ and to two emission wavelength maxima of $425 \mathrm{~nm}$ for $\mathrm{AFB}_{1}, \mathrm{AFB}_{2}, \mathrm{AFM}_{1}, \mathrm{AFM}_{2}$, and AFL and $450 \mathrm{~nm}$ for $\mathrm{AFG}_{1}, \mathrm{AFG}_{2}$ and $\mathrm{AFP}_{1}$; and an autosampler (G1329A Series DE64761666). The chromatographic column was a VDS Optilab VDSpher $100 \mathrm{C} 18-\mathrm{E} 5 \mu \mathrm{m} 250 \mathrm{~mm} \times 4.6 \mathrm{~mm}$ that was maintained at room temperature $\left(22^{\circ} \mathrm{C}\right)$ with a mobile phase of water:ACN:methanol $(65: 15: 20 \mathrm{v} / \mathrm{v} / \mathrm{v})$ that was degassed for $30 \mathrm{~min}$ under vacuum and added at a flux of $1.0 \mathrm{~mL} / \mathrm{min}$. The injection volume was $60 \mu \mathrm{L}$.

\section{Statistical analysis}

The statistical analysis was performed using Minitab version 
Citation: Vargas-Ortiz M, Carvajal-Moreno M, Hernández-Camarillo E, Ruiz-Velasco S, Rojo-Callejas F (2017) Unreported Aflatoxins and Hydroxylate Metabolites in Artisanal Oaxaca Cheese from Veracruz, Mexico. Biochem Anal Biochem 6: 322. doi: 10.4172/2161-1009.1000322

Page 4 of 9

16. Variance analyses with the Tukey test at $95 \%$ were performed in triplicate, considering each cheese as an experimental unit. The graphs showing the data from the Tukey test and the standard deviations were produced using Kaleida Graph version 3.5. Kruskal-Wallis statistical analysis was used to find significance and differences of AFs. The Wilcoxon Rank Sums test was performed to find differences for each pair of samples and Bonferroni corrections of the samples.

\section{Results and Discussion}

\section{Validation parameters}

The Limit of Detection (LOD) in $\mathrm{ng}^{-1}$ and recovery percentage

\begin{tabular}{|c|c|c|c|c|}
\hline \multirow{2}{*}{ Aflatoxin } & \multirow{2}{*}{$\begin{array}{l}\text { LOD } \\
\left(\mathbf{n g} \mathbf{g}^{-1}\right)\end{array}$} & \multicolumn{2}{|l|}{ Linearity (curves) } & \multirow{2}{*}{$\begin{array}{l}\text { Recovery } \\
\text { percentage }\end{array}$} \\
\hline & & Retention time (minutes) & $\mathbf{R}^{2}$ & \\
\hline $\mathrm{AFB}_{1}$ & 0.01 & $7.085-8.849$ & 0.9986 & $97 \%$ \\
\hline $\mathrm{AFB}_{2}$ & 0.02 & $17.452-20.228$ & 0.9988 & $95 \%$ \\
\hline $\mathrm{AFG}_{1}$ & 0.05 & $5.722-5.876$ & 0.9626 & $93 \%$ \\
\hline $\mathrm{AFG}_{2}$ & 0.05 & $11.215-14.513$ & 0.9946 & $96 \%$ \\
\hline $\mathrm{AFM}_{1}$ & 0.01 & 8.514-8.769 & 0.9834 & $95 \%$ \\
\hline $\mathrm{AFM}_{2}$ & 0.05 & $20.208-22.447$ & 0.9946 & $97 \%$ \\
\hline $\mathrm{AFP}_{1}$ & 0.05 & $15.563-19.318$ & 0.9960 & $95 \%$ \\
\hline AFL & 0.01 & $3.032-5.569$ & 0.9978 & $98 \%$ \\
\hline
\end{tabular}

Table 1: Validation parameters of the study of aflatoxins and hydroxylates.
(Rec\%) for AFs were $\mathrm{AFB}_{1}$ (LOD 0.01, Rec 97\%), $\mathrm{AFB}_{2}$ (LOD 0.02, Rec 95\%), $\mathrm{AFG}_{1}$ (LOD 0.05, Rec 93\%), AFG (LOD 0.05, Rec 96\%), AFM (LOD 0.01, Rec 95\%), AFM (LOD 0.05, Rec 97\%), AFP (LOD 0.05 , Rec 95\%) and AFL (LOD 0.01, Rec 98\%). These data, the retention times and $\mathrm{R}^{2}$ are given in Table 1 .

\section{Quantification of all AF}

The averages of the AFs detected in the 30 samples of artisanal cheese were as follows: $\mathrm{AFB}_{1}\left(11.2 \mathrm{ng} \mathrm{g}^{-1}\right)$ in $77 \%(23 / 30)$; AFL (19.1 $\left.\mathrm{ng} \mathrm{g}^{-1}\right)$ in $70 \%(21 / 30) ; \mathrm{AFG}_{2}\left(0.2 \mathrm{ng} \mathrm{g}^{-1}\right)$ in 63\% (19/30); $\mathrm{AFM}_{1}(3.0 \mathrm{ng}$ $\left.\mathrm{g}^{-1}\right)$ in $53 \%(16 / 30)$; $\operatorname{AFP}_{1}\left(0.1 \mathrm{ng} \mathrm{g}^{-1}\right)$ in $50 \%(15 / 30) ; \mathrm{AFM}_{2}(0.2 \mathrm{ng}$ $\left.\mathrm{g}^{-1}\right)$ in $20 \%(6 / 30)$; $\mathrm{AFG}_{1}\left(0.03 \mathrm{ng} \mathrm{g}^{-1}\right)$ in $13 \%(4 / 30)$; and $\mathrm{AFB}_{2}$ in only $3 \%(1 / 30)$ traces ( $<\mathrm{LOD})$, as shown in Table 2 and Figures $4-6$. In the chromatograms the same letters mean that the samples were statistically the same, and were analyzed in a variance analysis with Tukey Test $(\mathrm{P}<0.05)$.

$\mathrm{AFB}_{1}$ and $\mathrm{AFL}$ were the most abundant AFs. The $\mathrm{AFB}_{1}$ was not a product of the cow metabolism but rather indicated that maize starch had been added during the manufacturing of the cheese. This addition is legal [33] and accepted for fresh cheeses, but it is not good practice from the point of view of $\mathrm{AF}$ contamination. The amount of $\mathrm{AFB}_{1}$ was very high, and it is the most carcinogenic $\mathrm{AF}$. $\mathrm{AFB}_{1}$ transforms itself into AFL, which is the interconverting hydroxylate form [34]. These

\begin{tabular}{|c|c|c|c|c|c|c|c|c|c|c|}
\hline \multicolumn{11}{|c|}{ Aflatoxins $\mathbf{n g ~ g}^{-1}$} \\
\hline Origin in Veracruz & Sample & $\mathrm{AFB}_{1}$ & $\mathrm{AFB}_{2}$ & $\mathbf{A F G}_{1}$ & $\mathrm{AFG}_{2}$ & $\mathrm{AFM}_{1}$ & $\mathrm{AFM}_{2}$ & $\mathrm{AFP}_{1}$ & AFL & $\mathrm{AFt}$ \\
\hline Tlalixcoyan & 1 & 0.1 & 0 & 0 & 0 & 0.03 & 3.43 & 0 & 71.0 & 74.5 \\
\hline Jamapa & 2 & 0 & 0 & 0 & 0.5 & 0 & 0 & 0.32 & 10.6 & 12.6 \\
\hline Jamapa & 3 & 0.1 & 0 & 0 & 0.1 & 0 & 0 & $<$ LOD & 25.3 & 25.5 \\
\hline La Mixtequilla & 4 & 0.03 & 0 & 0 & 0 & 0.01 & 0 & 0 & 13.9 & 13.9 \\
\hline Soledad de Doblado & 5 & 0.1 & 0 & $<$ LOD & 0 & 0.7 & 0 & $<\mathrm{LOD}$ & 2.9 & 3.8 \\
\hline Unknown & 6 & 0.1 & 0 & $<$ LOD & 0.3 & 0 & 0 & 0 & 9.9 & 10.3 \\
\hline Unknown & 7 & 0 & 0 & 0.1 & 3.1 & 0 & 0 & 0 & 0.02 & 3.2 \\
\hline Unknown & 8 & 0 & 0 & 0 & 0 & 0.04 & 0 & 0 & 2.1 & 2.5 \\
\hline Unknown & 9 & 0.6 & 0 & 0 & 0.6 & 0.03 & 0.6 & $<$ LOD & 24.7 & 26.6 \\
\hline La Antigua & 10 & 9.4 & 0.02 & 0 & 0.1 & 8.5 & 0 & 1.25 & 104.2 & 123.5 \\
\hline Unknown & 11 & 0.04 & 0 & 0 & 0.5 & 0 & 0 & 0 & 12.4 & 13.0 \\
\hline La Mixtequilla & 12 & 0 & 0 & 0 & 0 & 0.9 & 0 & $<$ LOD & 47.9 & 48.9 \\
\hline Soledad de Doblado & 13 & 0 & 0 & 0 & 0.2 & 2.5 & $<$ LOD & $<$ LOD & 45.2 & 47.9 \\
\hline Tlalixcoyan & 14 & 2.8 & 0 & 0 & 0.1 & 0.1 & $<$ LOD & 0 & 45.2 & 48.1 \\
\hline Tlalixcoyan & 15 & 0.02 & 0 & 0 & 0.1 & 30.6 & 0 & 0 & 0 & 30.6 \\
\hline Unknown & 16 & 0 & 0 & 0 & 0 & 0.1 & 0 & $<$ LOD & 51.0 & 51.1 \\
\hline Malibran market & 17 & 37.1 & 0 & 0 & 0 & 3.2 & $<$ LOD & 0 & 0 & 40.4 \\
\hline Unknown & 18 & 37.9 & 0 & 0 & 0.1 & 0 & 0 & $<$ LOD & 0 & 38.0 \\
\hline Tierra Blanca & 19 & 38.7 & 0 & 0 & 0.6 & 0 & 0 & $<$ LOD & 0 & 39.2 \\
\hline Boca el Río & 20 & 36.7 & 0 & 0 & 0 & 0 & 0 & $<$ LOD & 0 & 36.8 \\
\hline Unknown & 21 & 49.2 & 0 & 0 & 0 & 0 & 0 & 0 & 0 & 49.2 \\
\hline Soledad de Doblado & 22 & 37.9 & 0 & 0 & 0 & 0 & 2.62 & $<$ LOD & 1.8 & 42.4 \\
\hline Unknown & 23 & 0 & 0 & 0 & 0.2 & 41.8 & 0 & 0 & 0 & 42.0 \\
\hline Soledad de Doblado & 24 & 48.0 & 0 & 0 & 0.3 & 0.01 & 0 & 0 & 0 & 48.3 \\
\hline Malibrán market & 25 & 0.2 & 0 & 0 & 0.1 & 0.7 & 0 & 0 & 26.9 & 27.8 \\
\hline Unknown & 26 & 0.3 & 0 & 0.7 & 0.1 & 0 & 0 & 0 & 20.0 & 21.1 \\
\hline Unknown & 27 & 0.4 & 0 & 0 & 0.1 & 0 & 0 & $<$ LOD & 24.7 & 25.2 \\
\hline Unknown & 28 & 0.3 & 0 & 0 & 0 & 0 & 0 & 0 & 16.2 & 16.5 \\
\hline La Joya, Jalapa & 29 & 3.0 & 0 & 0 & 0.2 & 0 & 0 & $<$ LOD & 17.4 & 20.6 \\
\hline Unknown & 30 & 32.6 & 0 & 0 & 0.2 & 0.04 & 0 & $<$ LOD & 0 & 32.8 \\
\hline Sum* & & 335.3 & 0.02 & 0.8 & 7.3 & 89.6 & 6.7 & 3.5 & 573 & 1016 \\
\hline Average & & 11.2 & $<$ LOD & 0.03 & 0.2 & 3.0 & 0.2 & 0.1 & 19.1 & 33.9 \\
\hline
\end{tabular}

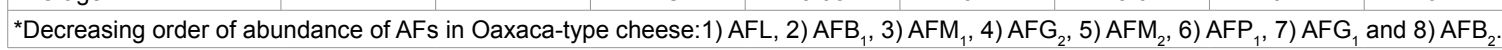

Table 2: Averages of triplicate counts of reported and unreported aflatoxins in artisanal Oaxaca-type cheeses of Veracruz. 
LU
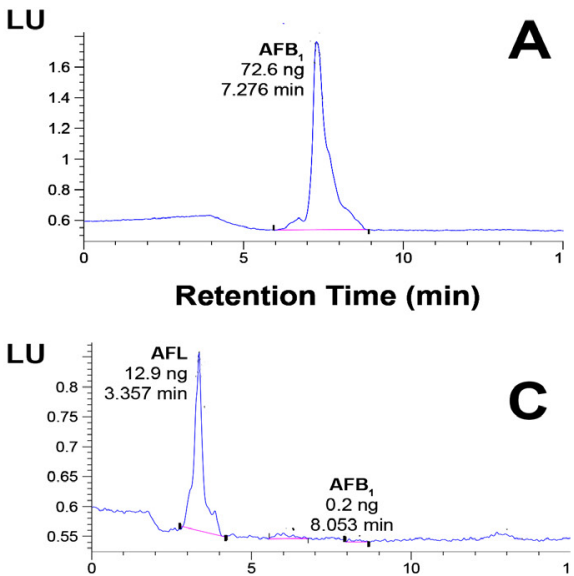

Retention Time (min)

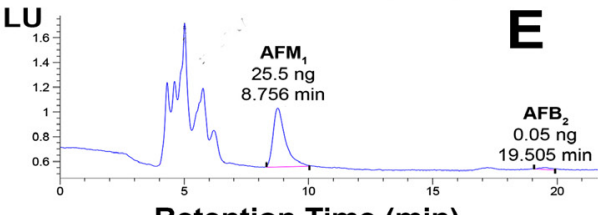

Retention Time (min)

LU

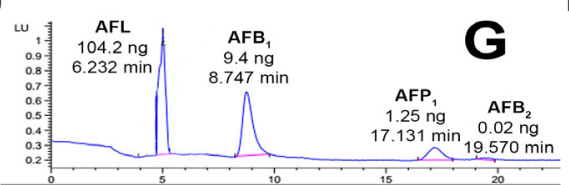

Retention Time (min)

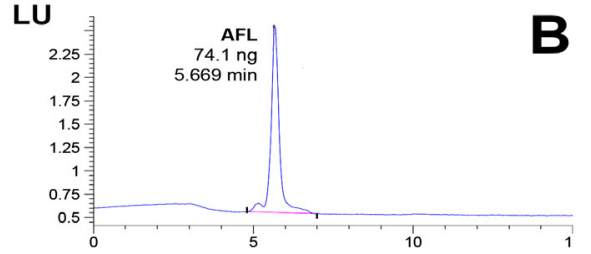

Retention Time (min)

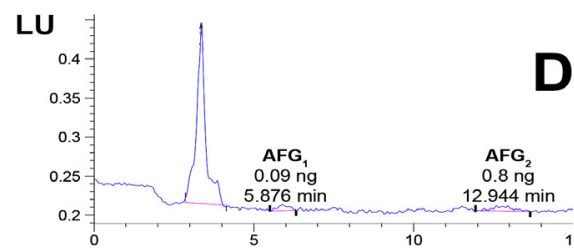

Retention Time (min)

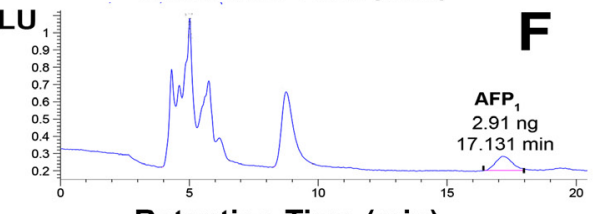

Retention Time (min)

LU

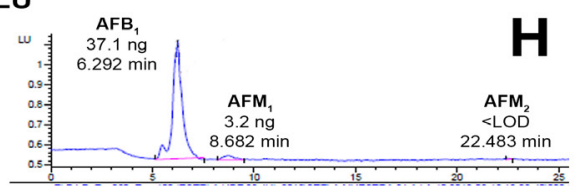

Retention Time (min)

Figure 4: Chromatograms of non-reported Aflatoxins found in Oaxaca-type cheese in the City of Veracruz. LU=Concentration in Luminiscence Units. The fluorescence data of AFs: a) $\mathrm{AFB}_{1}, \mathrm{AFB}_{2}, \mathrm{AFM}_{1}, \mathrm{AFM}_{2} \mathrm{Exc}=360, \mathrm{Em}=425 \mathrm{~nm}$, and b) $A F G_{1}, \mathrm{AFG}_{2}$ and $\mathrm{AFP}_{1}$ at, $E x \mathrm{C}=360 \mathrm{~nm}$ and $E \mathrm{~m}=450 \mathrm{~nm}$. A) $A F B_{1}$ in sample 24 replication (rep) 1; B) AFL in sample 14 rep 1; C) $A F L$ and $A F B_{1}$ sample 6 rep 2 and D) $A F G_{1}$ and $A F G_{2}$ sample 6 rep 2; E) $A F M_{1}$ and $A F B_{2}$ sample 10 rep 2 and $F$ ) $A F P_{1}$ sample 10 rep 2; G) $A F L, A F B_{1}, A F P_{1}$ and $A F B_{2}$ sample 10 rep 2; and $\left.H\right) A F B_{1}, A F M_{1}$ and $A F M_{2}$ (<LOD) sample 17 rep 1.
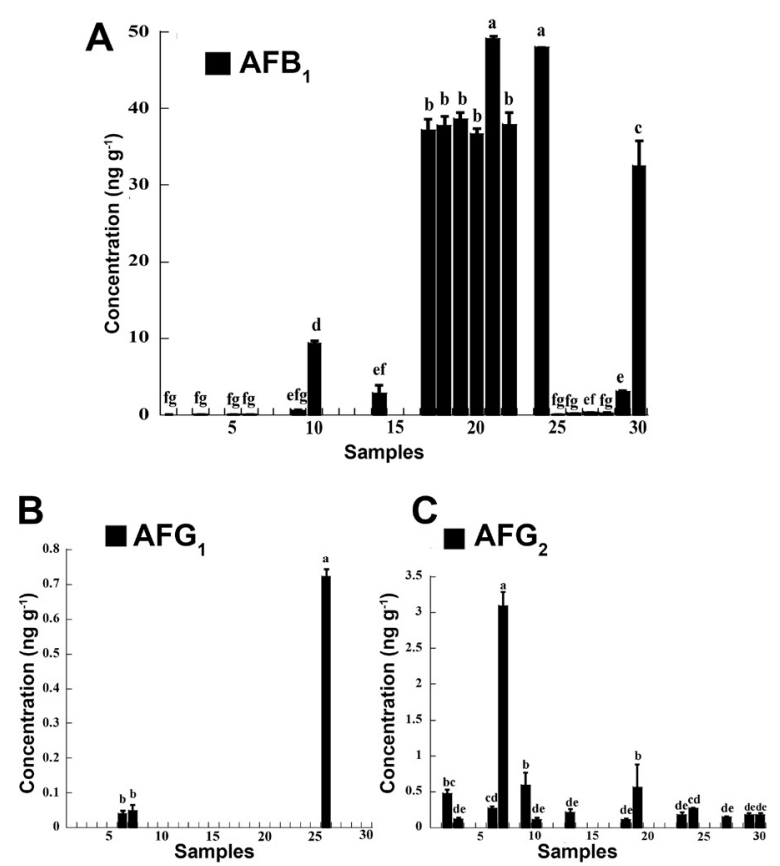

Figure 5: Unreported aflatoxins (A) $A F B_{1},(B) A F G_{1}$ and (C) $A F G_{2}$. The same letters represent samples statistically the same with Tukey test $(P<0.05)$. No $\mathrm{AFB}_{2}$ was detected.
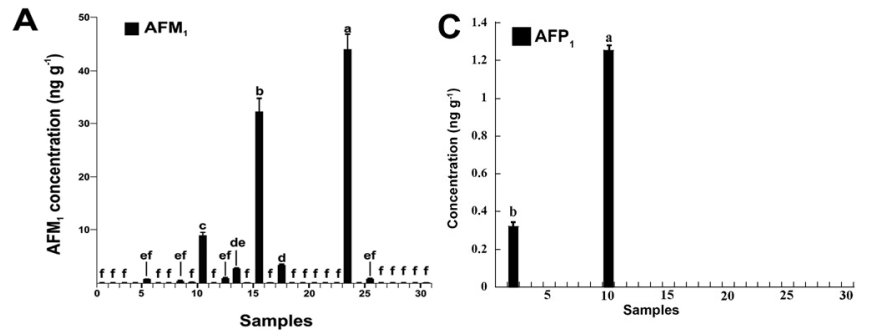

B
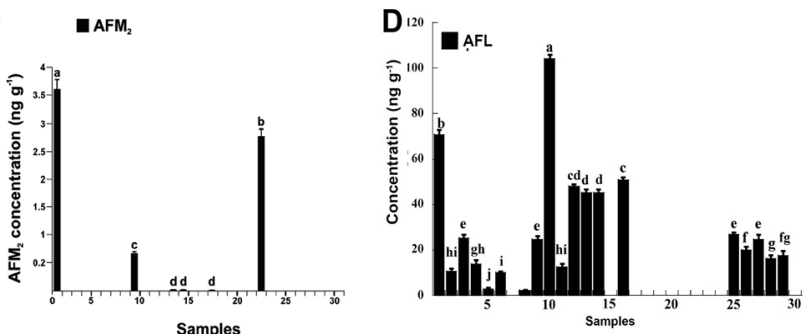

Figure 6: Reported $\mathrm{AFM}_{1}(\mathrm{~A})$ and $\mathrm{AFM}_{2}(\mathrm{~B})$, and non-reported aflatoxin hydroxylates $\mathrm{AFP}_{1}(\mathrm{C})$ and Aflatoxicol $(D)$ in artisanal cheese of Veracruz. The same letters represent samples statistically the same with Tukey test $(P<0.05)$.

two toxic metabolites are more frequent in Oaxaca-type cheese than are $\mathrm{AFM}_{1}$ and $\mathrm{AFM}_{2}$. Other $\mathrm{AFs}$, such as $\mathrm{AFP}_{1}$ and $\mathrm{AFG}_{1}$, were present in trace amounts [19], and $\mathrm{AFG}_{2}$ appeared more frequently. AFL can be formed through the enzymatic or synthetic reduction of $\mathrm{AFB}_{1}$, and 
Page 6 of 9

\begin{tabular}{|c|c|c|}
\hline Aflatoxin & Chi-square (29 df) & p-value \\
\hline AFB $_{1}$ & 44.897 & 0.0302 \\
\hline AFB $_{2}$ & 29.000 & 0.4651 \\
\hline $\mathrm{AFG}_{1}$ & 26.180 & 0.6159 \\
\hline $\mathrm{AFG}_{2}$ & 41.971 & 0.0565 \\
\hline $\mathrm{AFP}_{1}$ & 42.646 & 0.0491 \\
\hline df=Degrees of freedom, $p=$ Probability & \\
\hline
\end{tabular}

Table 3: Kruskal-Wallis statistical analysis to find significance and differences of aflatoxins.

\begin{tabular}{|c|c|c|c|c|c|c|}
\hline Sample & Mean & Median & $\begin{array}{l}\text { Standard } \\
\text { deviation }\end{array}$ & $\begin{array}{c}\text { Standard } \\
\text { error }\end{array}$ & $\begin{array}{c}\text { Equal } \\
\text { medians }\end{array}$ & $\begin{array}{l}\text { Bonferroni } \\
\text { correction }\end{array}$ \\
\hline 4 & 0.0267 & 0 & 0.0462 & 0.0267 & a & $a$ \\
\hline 11 & 0.0400 & 0 & 0.0693 & 0.0400 & $a$ & a \\
\hline 1 & 0.0633 & 0 & 0.1097 & 0.0633 & $a$ & $a$ \\
\hline 16 & 0.0633 & 0 & 0.1097 & 0.0633 & a & a \\
\hline 6 & 0.0667 & 0 & 0.1155 & 0.0667 & a & a \\
\hline 8 & 0.0867 & 0 & 0.1501 & 0.0867 & $a$ & $a$ \\
\hline 3 & 0.0967 & 0 & 0.1674 & 0.0967 & a & a \\
\hline 26 & 0.1133 & 0 & 0.1963 & 0.1133 & $a$ & $a$ \\
\hline 5 & 0.1267 & 0.13 & 0.1250 & 0.0722 & $a$ & $a$ \\
\hline 25 & 0.1700 & 0.17 & 0.1700 & 0.0982 & a & a \\
\hline 28 & 0.2700 & 0.37 & 0.2364 & 0.1365 & $a$ & $a$ \\
\hline 27 & 0.3000 & 0.3 & 0.3000 & 0.1732 & $a$ & $a$ \\
\hline 9 & 0.3467 & 0.36 & 0.3402 & 0.1964 & a & a \\
\hline 14 & 2.7933 & 0 & 4.8382 & 2.7933 & a & a \\
\hline 29 & 3.0067 & 0.04 & 5.1731 & 2.9867 & $a$ & $a$ \\
\hline 10 & 9.3800 & 0.12 & 16.1428 & 9.3201 & $a$ & $a$ \\
\hline 17 & 14.2433 & 0 & 24.6702 & 14.2433 & $a, b$ & a \\
\hline 15 & 15.4467 & 0.05 & 26.7111 & 15.4217 & $a, b, c$ & $a$ \\
\hline 30 & 22.9200 & 23.53 & 22.6212 & 13.0603 & $a, b, c$ & $a$ \\
\hline 24 & 24.1833 & 0 & 41.8868 & 24.1833 & $a, b, c$ & a \\
\hline 22 & 32.1767 & 45.81 & 27.9737 & 16.1507 & $a, b, c$ & $a$ \\
\hline 20 & 36.7400 & 44.06 & 13.6778 & 7.8969 & b, c & $\mathrm{b}$ \\
\hline 18 & 37.8667 & 34.34 & 8.1166 & 4.6861 & $b, c$ & $b$ \\
\hline 19 & 38.6467 & 38.3 & 0.9488 & 0.5478 & $b, c$ & $\mathrm{~b}$ \\
\hline 21 & 49.1500 & 45.89 & 7.4182 & 4.2829 & $b, c$ & $b$ \\
\hline
\end{tabular}

Table 4: Wilcoxon Rank sums test to find difference for every pair of samples.

\begin{tabular}{|c|c|c|c|c|c|c|}
\hline Sample & Mean & Median & $\begin{array}{c}\text { Standard } \\
\text { deviation }\end{array}$ & $\begin{array}{c}\text { Standard } \\
\text { error }\end{array}$ & $\begin{array}{c}\text { Equal } \\
\text { medians }\end{array}$ & $\begin{array}{c}\text { Bonferroni } \\
\text { correction }\end{array}$ \\
\hline 30 & 0.0033 & 0 & 0.0058 & 30 & a, c & a \\
\hline 9 & 0.0067 & 0 & 0.0116 & 9 & a, c & a \\
\hline 22 & 0.0067 & 0 & 0.0116 & 22 & a, c & a \\
\hline 5 & 0.0100 & 0.01 & 0.0100 & 5 & a, c & a \\
\hline 13 & 0.0100 & 0 & 0.0173 & 13 & a, c & a \\
\hline 19 & 0.0100 & 0 & 0.0173 & 19 & a, c & a \\
\hline 27 & 0.0100 & 0 & 0.0173 & 27 & a, c & a \\
\hline 12 & 0.0133 & 0 & 0.0231 & 12 & a, c & a \\
\hline 18 & 0.0200 & 0 & 0.0346 & 18 & a, c & a \\
\hline 20 & 0.0367 & 0 & 0.0635 & 20 & a, c & a \\
\hline 29 & 0.0400 & 0 & 0.0693 & 29 & a, c & a \\
\hline 2 & 0.1600 & 0 & 0.2771 & 2 & a, b, c & a \\
\hline 7 & 22.9433 & 1.20 & 38.7044 & 7 & a, b, c & a \\
\hline 16 & 0.0250 & 0.02 & 0.0229 & 16 & a, b & b \\
\hline 10 & 1.2500 & 0.72 & 1.4686 & 10 & b & b \\
\hline
\end{tabular}

Table 5: Statistics for $\mathrm{AFP}_{1}$ in the 15 samples that have values different than zero.

\begin{tabular}{|c|l|l|c|c|}
\hline Sample & Mean & Median & Standard deviation & Standard error \\
\hline 7 & 0.0212 & 0.007 & 0.0250 & 0.0144 \\
\hline 22 & 1.8033 & 0 & 3.1235 & 1.8033 \\
\hline
\end{tabular}

\begin{tabular}{|c|c|c|c|c|}
\hline 8 & 2.0567 & 1.95 & 0.5676 & 0.3277 \\
\hline 5 & 2.9143 & 1.46 & 2.9173 & 1.6843 \\
\hline 6 & 5.7000 & 4.18 & 6.5928 & 3.8063 \\
\hline 2 & 10.6233 & 11.14 & 1.1829 & 0.6829 \\
\hline 4 & 12.5100 & 12.30 & 10.8265 & 6.2507 \\
\hline 26 & 13.6633 & 16.37 & 12.5312 & 7.2349 \\
\hline 25 & 14.9100 & 17.13 & 13.9333 & 8.0444 \\
\hline 28 & 16.1967 & 21.15 & 10.1509 & 5.8607 \\
\hline 29 & 17.4167 & 19.94 & 16.3021 & 9.4120 \\
\hline 3 & 20.9867 & 4.97 & 32.142 & 18.5572 \\
\hline 27 & 24.6667 & 31.80 & 12.4507 & 7.1884 \\
\hline 9 & 24.7367 & 24.20 & 8.5976 & 4.9638 \\
\hline 1 & 30.7633 & 28.58 & 31.9111 & 18.4239 \\
\hline 13 & 45.1533 & 64.52 & 39.2355 & 22.6526 \\
\hline 14 & 45.1933 & 61.44 & 39.6504 & 22.8921 \\
\hline 12 & 47.9300 & 70.70 & 40.4737 & 23.3675 \\
\hline 16 & 50.9700 & 34.41 & 29.7631 & 17.1837 \\
\hline 10 & 104.2370 & 142.74 & 67.6794 & 39.0747 \\
\hline
\end{tabular}

Table 6: Wilcoxon Rank Sums of Values of 20 samples with AFL concentrations different from zero.

it has high toxicity and carcinogenicity [34]. Although the toxicity of AFL is 18 times lower than that of $\mathrm{AFB}_{1}$, both molecular structures have similar potency to form an exo-epoxide analogue that can bind to DNA [34]. AFL interconverts with $\mathrm{AFB}_{1}$, has electrochemical properties like those of $\mathrm{AFB}_{1}$, and these compounds have been experimentally demonstrated to have high carcinogenicity and toxicity.

$\mathrm{AFM}_{1}$ contamination was in third place in Oaxaca-type cheese samples (Table 2), consistent with the results obtained for other kinds of cheese, such as cream cheese [35], white pickled cheese [36], sheep curd [37], Grana Padano cheese [38], parmesan [39], Turkish kashar cheese [40], and Serbian hard cheese [41]. $\mathrm{AFM}_{2}$ contamination has been less frequently reported. There have been several studies [42] on carryover from cows fed $\mathrm{AFB}_{1}$-contaminated rations to $\mathrm{AFM}_{1}$ in milk. The degree of toxicity and carcinogenicity of AFs is in the following order: $B_{1}>G_{1}>B_{2}>G_{2}$.

We performed a Kruskal-Wallis analysis to find differences in the concentrations of $\mathrm{AFB}_{1}, \mathrm{AFB}_{2}, \mathrm{AFG}_{1}, \mathrm{AFG}_{2}, \mathrm{AFP}_{1}$ and $\mathrm{AFL}$ among the 30 samples, as shown in Table 3 . There were statistically significant differences among the samples for $\mathrm{AFB}_{1}$ and $\mathrm{AFP}_{1}$. For $\mathrm{AFG}_{2}$, the differences were not statistically significant at $5 \%$, but if a different significance value is considered ( $10 \%$, for example), the differences among the samples may be significant. Table 4 presents the Wilcoxon Rank Sums test to find the differences for each pair of samples for $A_{F B}$. We found that 21 of the 25 samples had concentrations that were not significantly different from zero, but when the Bonferroni correction was applied, these samples differed from the remaining four samples, 18 to 21 .

For $\mathrm{AFP}_{1}$, we found that 13 of the 15 samples had concentrations that were not significantly different from zero. When the Bonferroni correction was applied, these samples differed from the remaining two (samples 16 and 10). It is important to note that most samples had at least one replicate different from zero. Samples 2 and 5 had two replicates different from zero, and samples 10 and 16 had three replicates different from zero. Table 5 shows the statistics for $\mathrm{AFP}_{1}$ in the 15 samples that had values different from zero. Table 6 shows the Wilcoxon Rank Sums of Values of 20 samples with AFL concentrations different from zero. The Wilcoxon Rank Sums test for all the pairs indicated that there is some inconsistency in the results of the tests. This might be due to some of the samples having a very large variation coefficient. Employing 
Bonferroni correction, we found that all samples with observations different than zero were equal and significantly different than zero.

AFL is produced in several fungi: Aspergillus flavus, A. parasiticus, A. niger, Eurotium herbariorum, Rhizopus spp. and other non aflatoxicogenic A. flavus [43]. Reduction of the 1-keto group of $\mathrm{AFB}_{1}$ produces AFL [44]. AFL is equally carcinogenic as $\mathrm{AFB}_{1}$, so its formation is not a significant detoxification mechanism [45,46]. AFL has approximately $70 \%$ the mutagenicity of $\mathrm{AFB}_{1}$ [47], and it has two forms, $A(\mathrm{Ro})$ and $B$, both of which are produced from the biological reduction of $\mathrm{AFB}_{1}$ and mainly by Tetrahymena pyriformis, Dactylium dendroides and Rhizopus spp. AFL A is 18 times less toxic than $\mathrm{AFB}_{1}$ in the duckling biliary hyperplasia assay, and the biological activity of AFL $\mathrm{B}$ is unknown $[48,49]$. AFL is the major metabolite of $\mathrm{AFB}_{1}$ in many plants and animals, and it has been detected in milk [26,50], fermented dairy products [51], cereals and nuts [52], eggs [53], blood [54,55], human brain [56], the sera and liver of humans with kwashiorkor and marasmic kwashiorkor in Ghana and Nigeria [57-60], human urine [61], urine of heroin addicts [58], a breast-fed infant with neonatal hepatitis [62], the muscle of broiler chickens fed with contaminated diets [63], and poultry fed chronic low doses of mycotoxins, with the liver having the highest levels [64]. $\mathrm{AFB}_{1}, \mathrm{AFM}_{1}$ and $\mathrm{AFL}$ accumulate in the tissues and urine of calves $[65,66]$. AFL-DNA adducts that were produced in vivo were identical to those produced by $\mathrm{AFB}_{1}$ and had similar molecular dosimetry responses and toxicity to the target organ [67]. Regarding DNA adduction and hepatocarcinogenicity in rainbow trout, the tumorigenic potencies were $\mathrm{AFB}_{1}=1.00$, $\mathrm{AFL}=0.936, \mathrm{AFM}_{1}=0.086$. AFL is a more potent toxin than $\mathrm{AFM}_{1}$, which can reconvert with $\mathrm{AFM}_{1}$, becoming AFL $\mathrm{M}_{1}$ [68]. AFL-induced hepatocellular carcinomas in rats and fish have a lower tumor incidence than those induced by $\mathrm{AFB}_{1}$ [69]. There is an interconversion of $\mathrm{AFB}_{1}$ and AFL, mediated by intracellular enzymes in rat blood [70]; guinea pigs [71]; sharks, which reconvert $30 \%$ of AFL to $\mathrm{AFB}_{1}$ [72-74]; and cultured human epidermal cells [75]. AFL converts into $\mathrm{AFB}_{1}$, which is the most carcinogenic and toxic of all AFs [76]. AFL is oxidized readily back to $\mathrm{AFB}_{1}$, so it can serve as a 'reservoir' for $\mathrm{AFB}_{1}$ in vivo, thereby prolonging the effective lifetime in the body [77]. If $\mathrm{pH}$ has a role in the interconversion $\mathrm{AFB}_{1}-\mathrm{AFL}$, it could act in the normal human digestion of milk, where pepsin lowers the $\mathrm{pH}$. The isomerization of AFL to AFB was observed in culture media with a low culture $\mathrm{pH}$ [76].

The genotoxicity of $\mathrm{AFM}_{1}$ has been demonstrated by in vitro and in vivo experiments. The carcinogenic potency of $\mathrm{AFM}_{1}$ is $2 \%$ to $10 \%$ weaker than that of $\mathrm{AFB}_{1}$ [78]. Therefore, the Food Safety Commission of Japan in 2013 [78] concluded that the AFB that is present in animal feed is extremely unlikely to affect the health of humans who have consumed contaminated milk or other livestock products. However, AF and the hydroxylate metabolites are also genotoxic carcinogens and are more likely to be found in livestock products, so $\mathrm{AFB}_{1}$ contamination in feed and $\mathrm{AFM}_{1}$ contamination in milk need to be reduced as much as possible. In particular, attention should be paid to the fact that the intake of milk per $1 \mathrm{~kg}$ of body weight is higher in infants than in other age groups [78].

Risk assessment parameters for $\mathrm{AFB}_{1}, \mathrm{AFL}$ and $\mathrm{AFM}_{1}$ have been compared [79]. The virtually safe dose for AFL was 1.7 times higher than that for $\mathrm{AFB}_{1}$.

The incidence of hepatocellular carcinoma in rats and fish dosed with AFL was lower than that in animals treated with $\mathrm{AFB}_{1}$ at the same dosage. AFL in milk might still be a health hazard, particularly for infants whose staple diet is milk-based. AFM ${ }_{1}$ was not the most abundant $\mathrm{AF}$, and the risk increases when the AFL contamination in milk is added. $\mathrm{AFM}_{1}$ is possibly carcinogenic to humans and was classified as Group 2B by the IARC (1997) [69].

$\mathrm{AFM}_{1}$ has been found in Mexican milk [25], so its presence in cheese was not unexpected, where most AFs were metabolized to AFL. Autumn milk was significantly more contaminated with AFL $(p<0.0002) . A F B$ had no significant correlation with season, and it is not clear if the presence of vegetable oil helped to decrease the AFL contamination [26]. $\mathrm{AFB}_{1}$ was generally present in milk at trace levels $\left(0.05 \mathrm{mg} \mathrm{L}^{-1}\right.$ to $\left.0.42 \mathrm{mg} \mathrm{L}^{-1}\right)$ in $5.2 \%$ of the 290 samples [26] and is not considered a health risk, but cheese had more concentrated amounts ( 0.04 to $49.2 \mathrm{ng} \mathrm{g}^{-1}$ ), with an average of $11.2 \mathrm{ng} \mathrm{g}^{-1}$ in the 30 samples and can be considered a health risk.

The hydroxylates $\mathrm{AFP}_{1}$ and AFL are not accepted as toxicologically important in many countries. Polish and European Union legislations (Commission Regulation No. 152/98) agree that all food should be free from $\mathrm{AF}$ [80]. Oltipraz was shown to reduce $\mathrm{AFB}_{1}$ adduct biomarkers [81] and inhibit $\mathrm{AFM}_{1}$ production by bovine hepatocytes [82], so it can be used to lower the risk related to cheese consumption. It is necessary to balance the availability of milk in relation to the health risk, not only for cancer but also for other diseases, such as immune suppression, hepatitis and cirrhosis. This fact makes mycotoxin regulation difficult and very incomplete.

AFs are recurrent and occasionally unavoidable contaminants of milk, cereals and oilseeds, and their thermal stability rules out both pasteurization and ultrapasteurization as effective control methods. The best control strategy is to keep raw materials and feed under obligatory mycotoxin regulation. In the case of cheese, it is recommended not to add maize flour during the manufacturing process.

\section{Conclusion}

Although the legislation regarding maximum tolerance levels has attempted to decrease the level of AFM contamination in cheeses and although there is no direct evidence of human toxicity resulting from the consumption of cheese contaminated with AFs, the problem of ingesting $\mathrm{AFB}_{1}$ and $\mathrm{AFL}$ is still present in fresh cheeses, such as the artisanal Oaxaca cheese.

\section{Acknowledgments}

The authors thank the Instituto Tecnológico de Veracruz for the cheese sampling and the Instituto de Biología, Universidad Nacional Autónoma de México (IBUNAM) for the data analysis. The authors also thank IBUNAM's personnel: Noemí Chávez from the Secretaría Técnica, and Joel Villavicencio, Jorge López, Alfredo Wong, Celina Bernal, Diana Martínez and Julio César Montero provided valuable assistance with imaging, computer analysis and design. Additionally, we thank Georgina Ortega Leite and Gerardo Arévalo for library information.

\section{References}

1. INEGI, Instituto Nacional de Estadística, Geografía e Informática (2006) Encuesta industrial mensual. Cantidad y valor de ventas.

2. INEGI, Instituto Nacional de Estadística, Geografía e Informática (2008) Encuesta industrial mensual. Cantidad y valor de producción de los productos elaborados. Encuestas tradicionales en establecimientos.

3. SIAP (Servicio de Información Agroalimentaria y Pesquera), México (2015) Boletín de Leche enero-marzo de 2015, México.

4. FUNPROVER, Fundación produce Veracruz (2010) Reporte Técnico de Proyecto. Estudio y análisis del mercado de los productos del sistema bovinos de doble propósito en el Estado de Veracruz. Colegio de Postgraduados Veracruz. Xalapa, México.

5. Villanueva-Carvajal A, Esteban-Chávez M, Espinoza-Ortega A, Arriaga-Jordán CM, Domínguez-López A (2012) Oaxaca cheese:Flavour, texture and thei interaction in a Mexican traditional pasta filata type cheese. J Food 10:63-70. 
Citation: Vargas-Ortiz M, Carvajal-Moreno M, Hernández-Camarillo E, Ruiz-Velasco S, Rojo-Callejas F (2017) Unreported Aflatoxins and Hydroxylate Metabolites in Artisanal Oaxaca Cheese from Veracruz, Mexico. Biochem Anal Biochem 6: 322. doi: 10.4172/2161-1009.1000322

Page 8 of 9

6. OPS, Panamerican Health Organization (1983) Criteria of Environmental Health 11. Scientific Publication $N^{\circ} 453$. WHO, Washington, USA

7. Mohajeri FA, Ghalebi SR, Rezaeian M, Gheisari HR, Azad HK, et al. (2013). Aflatoxin M1 contamination in white and Lighvan cheese marketed in Rafsanjan, Iran. Food Control 33:525-527.

8. Murphy PA, Hendrich S, Landgren C, Bryant C (2006) Food mycotoxins:An update. J Food Sci 71:51-65.

9. Creppy EE (2002) Update of survey, regulation and toxic effects of mycotoxins in Europe. Toxicol Lett 127:19-28.

10. Kensler TW, Roebuck BD, Wogan GN, Groopman JD (2011) Aflatoxin:A 50-yea Odyssey of Mechanistic and Translational Toxicology. Toxicol Sci 120:28-48.

11. Carvajal M, Berumen J, Guardado-Estrada M (2012) The presence of AFB1FAPY adduct and human papilloma virus in cervical smears from cancer patients in Mexico. Food Addit Contam 29:258-268.

12. Harrison JC, Carvajal M, Garner RC (1993) Does aflatoxin exposure in the United Kingdom constitute a cancer risk? Environ Health Perspect 99:99-105.

13. IARC, International Agency for the Research of Cancer (2002) Overal evaluations of carcinogenicity:An updating of IARC Expert Committee, World Health Organization. Monograph pp. 82:171

14. Morgavi DP, Riley RT (2007) An historical overview of field disease outbreaks known or suspected to be caused by consumption of feeds contaminated with Fusarium toxins. Anim Feed Sci Technol 137:201-212.

15. Dragan RM, Marija Š, Tatjana B (2010) Real and Perceived Risks for Mycotoxin Contamination in Foods and feeds:Challenges for food safety control. Toxins 2:572-592.

16. Kamkar A (2006) A study on the occurrence of aflatoxin M1 in Iranian Feta cheese. Food Control 17:768-775.

17. Milićević DR, Škrinjar M, Baltić T (2010) Real and perceived risks for mycotoxin contamination in foods and feeds:Challenges for food safety control. Toxins 2:572-592.

18. Anfossi L, Baggiani C, Giovannoli C, D'Arco G, Passini C, et al. (2012) Occurrence of aflatoxin M1 in Italian cheese:Results of a survey conducted in 2010 and correlation with manufacturing, production season, milking animals and maturation of cheese. Food Control 25:125-130.

19. Shephards GS (2003) Aflatoxin and food safety:Recent African perspectives. J Toxicol Toxin Rev 22:267-286.

20. Brackett RE, Marth EH (1982) Association of aflatoxin M1 with casein. Z Lebensm Unters Forsch 174:439-441.

21. Yousef AE, Marth EH (1989) Stability and degradation of Aflatoxin M1. In Mycotoxins in Dairy products. Egmond HP van (edn). Elsevier Science, Publishing Co, Inc, New York, USA.

22. Deveci $O$ (2007) Change in the concentration of aflatoxin M1 during manufacture and storage of white pickled cheese. Food Control 18:1103-1107.

23. Oruc HH, Cibik R, Yilmaz E, Kalkanli O (2006) Distribution and stability of Aflatoxin M1 during processing and ripening of traditional white pickled cheese. Food Addit Contam 23:190-195.

24. El Khoury A, Atoui A, Yaghi J (2011) Analysis of aflatoxin M1 in milk and yogurt and AFM1 reduction by lactic acid bacteria used in Lebanese industry. Food Control 22:1695-1699.

25. Carvajal M, Bolaños A, Rojo F, Méndez I (2003) Aflatoxin M1 in pasteurized and ultrapasteurized milk with different fat content in Mexico. J Food Protect 66:1885-1892.

26. Carvajal M, Rojo F, Méndez I, Bolaños A (2003 b) Aflatoxin B1 and its interconverting metabolite Aflatoxicol in milk. Situation in Mexico. Food Addit Contam 20:1077-1086

27. R-Biopharm Rhone Ltd (2012) Easi-extract aflatoxin. Guía de uso para el usuario. RP71RP70N/V12/28.06.12. pp. 3-12. Block 10 Todd Campus, West of Scotland Science Park. Acre Road, Glasgow G20 0XA. UK.

28. Kok WTH (1994) Derivatization reactions for the determination of aflatoxins by liquid chromatography with fluorescence detection. J Chromatogr B 659:127-137.

29. Akiyama H, Goda Y, Tanaka T, Toyoda M (2001) Determination of aflatoxins B1 B2, G1 and G2 in spices using a multifunctional column clean-up. J Chromatogr A 932:153-157.
30. García MA, Soberón E, Cortés M, Rodríguez R, Herrera JL, et al. (2002) Guía de validación de métodos analíticos. Ed. Colegio Nacional de QFB, AC México, DF, México.

31. AOAC, Association of Official Analytical Chemists (2006) Natural toxins. In Official Methods of Analysis of AOAC International, (18 ${ }^{\text {th }}$ edn), Horwitz W, Latimer GW Jr, Trucksess MW (eds) 1-51. Gaithersburg (MD):AOAC International.

32. Cruz-Rueda V (2016) Curso de Validación de Métodos Analíticos. Centro de Capacitación R.H. World SA de CV.

33. Norma Oficial Mexicana NOM-243-SSA1-2010 (2010) Productos y Servicios fórmula láctea, producto lácteo combinado y derivados lácteos. Disposiciones y especificaciones sanitarias. Métodos de prueba.

34. Karabulut S, Paytakov G, Leszczynski J (2014) Reduction of aflatoxin B1 to aflatoxicol:A comprehensive DFT study provides clues to its toxicity. J Sci Food Agr 94:3134-3140.

35. Prandini A, Fallah AA, Jafari T, Fallah A, Rahnama M (2009 a) Determination of aflatoxin M1 levels in Iranian white and cream cheese. Food Chem Toxicol 47:1872-1875

36. Oruc HH, Cibik R, Yilmaz E, Kalkanli O (2006) Distribution and stability of Aflatoxin M1 during processing and ripening of traditional white pickled cheese. Food Addit Contam 23:190-195

37. Battacone G, Nudda A, Palomba M, Pascale M, Nicolussi P, et al. (2005) Transfer of aflatoxin B1 from feed to milk and from milk to curd and whey in dairy sheep fed artificially contaminated concentrates. J Dairy Sci 88:30633069

38. Manetta AC, Giammarco M, Di Giuseppe L, Fusaro I, Gramenzi A, et al. (2009) Distribution of aflatoxin M1 during Grana Padano cheese production from naturally contaminated milk. Food Chem 113:595-599.

39. Pietri A, Mulazzi A, Piva G, Bertuzzi T (2016) Fate of aflatoxin M1 during production and storage of parmesan cheese. Food Control 60:478-483.

40. Tekinşen KK, Eken HS (2008) Aflatoxin M1 levels in UHT milk and kashar cheese consumed in Turkey. Food Chem Toxicol 46:3287-3289.

41. Škrbić B, Antić I, Živančev J (2015) Presence of aflatoxin M1 in white and hard cheese samples from Serbia. Food Control 50:111-117.

42. Chopra RC, Chabra A, Prasad KSN, Dudhe A, Murthy TN, et al. (1999) Carryover of Aflatoxin M1 in milk of cows fed aflatoxin B1 contaminated ration. Indian J Anim Nutr 16:78-85.

43. Nakazato M, Morozumi S, Saito K, Fujinuma K, Nishima T, et al. (1991) Production of aflatoxins and aflatoxicols by Aspergillus flavus and Aspergillus parasiticus and metabolism of aflatoxin B1 by aflatoxin-non-producing Aspergillus flavus. Eisei Kagaku 37:107-116.

44. Detroy RW, Hesseltine CW (1970) Structure of a new transformation product of aflatoxin B1. Can J Biochem Physio 48:830-832.

45. Schoenhard GL, Hendricks JD, Nixon JE, Lee DJ, Wales JH, et al. (1981) Aflatoxicol-induced hepatocellular carcinoma in rainbow trout (Salmo gairdneri) and the synergistic effects of cyclopropenoid fatty acids. Cancer Res 41:1011-1014.

46. Peraica M, Radic B, Lucic A, Pavlovic M (1999) Toxic effects of mycotoxins in humans. Bull WHO 77:754-766.

47. Coulombe RA, Shelton DW, Sinnhuber RO, Nixon JE (1982) Comparative mutagenicity of aflatoxins using a Salmonella/trout hepatic enzyme activation system. Carcinogenesis 3:1261-1264.

48. Detroy RW, Hesseltine CW (1968) Isolation and biological activity of a microbial conversion product of aflatoxin B1. Nature 219:967.

49. Cole RJ, Cox RH (1981) Handbook of toxic fungal metabolites. NY Acad Press. USA.

50. Hsieh DPH (1983) Metabolism and transmission of mycotoxins. Proc of the Intern Symp on Mycotoxins (Cairo, Egypt), pp. 151-165.

51. Megalla SE, Mohran MA (1984) Fate of aflatoxin B1 in fermented dairy products. Mycopathologia 88:27-29.

52. Saito K, Nishijima M, Yasuda K, Kamimura H, Ibe A, et al. (1984) Analytica method for aflatoxins and aflatoxicols in cereals, nuts and their products. Studies on mycotoxins in foods. XVI. J Food Hyg Soc Japan 25:112-117. 
Citation: Vargas-Ortiz M, Carvajal-Moreno M, Hernández-Camarillo E, Ruiz-Velasco S, Rojo-Callejas F (2017) Unreported Aflatoxins and Hydroxylate Metabolites in Artisanal Oaxaca Cheese from Veracruz, Mexico. Biochem Anal Biochem 6: 322. doi: 10.4172/2161-1009.1000322

Page 9 of 9

53. Trucksess MW, Stoloff L, Young K, Wyatt RD, Miller BL (1983) Aflatoxicol and aflatoxins $\mathrm{B} 1$ and $\mathrm{M} 1$ in eggs and tissues of laying hens consuming aflatoxin contaminated feed. Poult Sci 62:2176-2182.

54. Wong ZA, Hsieh DPH (1978) Aflatoxicol:Major aflatoxin B1 metabolite in rat plasma. Science 200:325-327

55. Kumagai S, Nakano N, Aibara K (1983) Interactions of aflatoxin B1 and blood components of various species in vitro:interconversion of aflatoxin B1 and aflatoxicol in the blood. Toxicol Appl Pharmacol 67:292-301.

56. Oyelami OA, Maxwell SM, Adelusola KA, Aladekoma TA, Oyelese AO (1995) Aflatoxins in the autopsy brain tissue of children in Nigeria. Mycopathologia 132:35-38.

57. Apeagyei F, Lamplugh SM, Hendrickse RG, Affram K, Lucas S (1986) Aflatoxins in the livers of children with kwashiorkor from Ghana. Trop Geogr Med 38:273-276.

58. Hendrickse RG, Maxwell SM, Young R (1989) Aflatoxins and heroin. Proceedings of the international symposium on agricultural and biological aspects of aflatoxin related health hazards. J Toxicol:Toxin Rev 8:89-94.

59. De Vries HR, Maxwell SM, Hendrickse RG (1990) Aflatoxin excretion in children with kwashiorkor or marasmic kwashiorkor-A clinical investigation. Mycopathologia 110:1-9.

60. Oyelami OA, Maxwell SM, Adelusola KA, Aladekoma TA, Oyelese AO (1998) Aflatoxins in autopsy kidney specimens from children in Nigeria. $\mathrm{J}$ Toxicol Environ Health, Part A 55:317-323.

61. Lovelace CEA, Njapau H, Salter LF, Bayley AC (1982) Screening method for the detection of aflatoxin and metabolites in human urine:aflatoxins B1, G1, M1, B2a, G2a, aflatoxicols I and II. J Chromatogr 227:256-261.

62. Coulter JBS, Hendrickse RG, Lamplugh SM, MacFarlane SB, Moody JB, et al. (1986) Kwashiorkor — clinical studies in Sudanese children. Trans R Soc Trop Med Hyg 35:360-365.

63. Fernández A, Verde MT, Gascón M, Ramos JJ, Gómez J (1994), Aflatoxin and its metabolites in tissues from laying hens and broiler chickens fed a contaminated diet. J Sci Food Agric 65:407-414.

64. Micco C, Miraglia M, Onori R, Brera C, Mantovani A, et al. (1988) Long term administration of low doses of mycotoxins to poultry. 1. Residues of aflatoxin B1 and its metabolites in broilers and laying hens. Food Addit Contam 5:303-308.

65. Van der Linde JA, Frens AM, De longh M, Vles RO (1964) Inspection of milk from cows fed aflatoxin containing groundnut meal. Tijdschr Diergeneeskd 89:1082-1088.

66. Sabino M, Purchio A, Milanez TV (1995) Aflatoxins B1, M1 and aflatoxicol in tissues and urine of calves receiving aflatoxin. Food Addit Contam 12:467-472.

67. Bailey GS, Dashwood R, Loveland PM, Pereira C, Hendricks JD (1998) Molecular dosimetry in fish:quantitative target organ DNA adduction and hepatocarcinogenicity for four aflatoxins by two exposure routes in rainbow trout. Mutat Res 399:233-244.

68. Bailey GS, Loveland PM, Pereira C, Pierce D, Hendricks JD, et al. (1994)
Quantitative carcinogenesis and dosimetry in rainbow trout for aflatoxin B1 and aflatoxicol, two aflatoxins that form the same DNA adduct. Mutat Res 313:25-38.

69. IARC (International Agency for Research on Cancer) (1997) Naturally occurring aflatoxins (Group 1), aflatoxin M1 (Group 2B) 08/21/1997. Monographs on the evaluation of carcinogenic risks to humans. Some Naturally Occurring Substances:Food items and constituents, heterocyclic aromatic amines and mycotoxins 56:5.1-5.5, Lyon France.

70. Chang WM, Lin JK, Wu KC, Hsiung KP (1985) In vitro interconversion of aflatoxin B1 and aflatoxicol by rat erythrocytes. Biochem Pharmacol 34:25662569

71. Liu L, Nakatsu K, Massey TE (1993) In vitro cytochrome P450 monooxygenase and prostaglandin $\mathrm{H}$-synthase mediated aflatoxin $\mathrm{B} 1$ biotransformation in guinea pig tissues:effects of beta-naphthoflavone treatment. Arch Toxicol 67:379-385.

72. Troxel CM, Buhler DR, Hendricks JD, Bailey GS (1997a) CYP1A induction by beta-naphthoflavone, Aroclor 1254, and 2,3,7,8-tetrachlorodibenzo-p-dioxin and its influence on aflatoxin B1 metabolism and DNA adduction in zebrafish (Danio rerio). Toxicol Appl Pharmacol 146:69-78.

73. Troxel CM, Reddy AP, O'Neal PE, Hendricks JD, Bailey GS (1997b) In vivo aflatoxin B1 metabolism and hepatic DNA adduction in zebrafish (Danio rerio) Toxicol Appl Pharmacol 143:213-220.

74. Bodine AB, Luer CA, Gangjee SA, Walsh CJ (1989) In vitro metabolism of the pro-carcinogen aflatoxin B1 by liver preparations of the calf, nurse shark and clearnose skate. Comp Biochem Physiol 94C:447-453.

75. Walsh AA, Hsieh DPH, Rice RH (1992) Aflatoxin toxicity in cultured human epidermal cells:stimulation by 2,3,7,8-tetrachlorodibenzo-p-dioxin Carcinogenesis 13:2029-2033.

76. Nakazato M, Morozumi S, Saito K, Fujinuma K, Nishima T, et al. (1990) Interconversion of aflatoxin B1 and aflatoxicol by several fungi. Appl Environ Microbiol 56:1465-1470.

77. Wong ZA, Hsieh DPH (1980) The comparative metabolism and toxicokinetics of aflatoxin B1 in monkey, rat and mouse. Toxicol Appl Pharmacol 55:115-125.

78. FSCJ, Food Safety Commission of Japan (2013) Food Safety. Official Journa of Food Safety Commission. November $20^{\text {th }}, 2013$.

79. Kuiper-Goodman T (1990) Uncertainties in the risk assessment of three mycotoxins:aflatoxin, ochratoxin, and zearalenone. Can J Physiol Pharmaco 68:1017-1024

80. Postupolski J, Rybinska K, Szczesna M, Karlowski K, Ledzion E (1999) The review of the European Union documents relating to contamination of aflatoxins in food. Roczniki Panstwowego Zakladu Higieny 50:57-67.

81. Li Y, Su J, Qin L, Egner PA, Wang J, et al. (2000) Reduction of aflatoxin B adduct biomarkers by Oltipraz in the tree shrew (Tupaia belangeri chinensis). Cancer Lett 154:79-83.

82. Kuilman MEM, Maas RFM, Woutersen-van Nijnanten FMA, Fink-Gremmels $J(2000)$ Inhibition of aflatoxin M1 production by bovine hepatocytes after intervention with oltipraz. Vet Quartrly 22:30-35. 